\title{
Assessing Critical Competence of Third Diploma Students of Sanitation Using SOP-Based Assessment
}

\author{
Nurlaila Marasabessy ${ }^{1, *}$ Jumarni Ely $^{2}$ Damayanti S.S. Sohilauw ${ }^{3}$ \\ ${ }^{123}$ Politeknik Kesehatan Kemenkes Maluku \\ *Email:nurlailaahmad@ rocketmail.com
}

\begin{abstract}
Third diploma graduates in accordance with the Indonesian National Qualification Framework/Kerangka Kualifikasi Nasional Indonesia (KKNI), are at required to have level 5 abilities, one of them is to mastering the theoretical concepts of certain areas of knowledge in general, as well as being able to formulate procedural problem solving. To perform the procedural competence of these students, definitely, standard operational procedures (SOP) are required for each course practice. To assess whether the student has had such procedural competence, a valid and reliable measuring instrument is required. The purpose of this research is to compose critical competency assessment instruments of third diploma of sanitation students, based on standard operational procedures (SOP). The preparation of student critical competency assessment instruments is carried out for each practical course. In addition to the review by experts, it is also necessary to conduct a review by all lecturers and instructors who are masters of practical courses in the third diploma of Sanitation Program. The review is conducted using an instrument adapted from the Learning Object Review Instrument/LORI. The results of the review by 16 (sixteen) lecturers and instructors is determined using an strument, with a rating score between 1 (low) to 5 (high). The review conducted by lecturers and instructors shows that the average lecturer / instructor gives a score between 3 to 5 for all aspects of the assessment, so it can be interpreted broadly that the instrument gets a positive response and is able to answer the learning objectives.
\end{abstract}

Keywords: SOP-Based Assessment, critical competence, student.

\section{INTRODUCTION}

The profile of a health diploma graduate student has critical and supporting abilities. Third diploma graduates in accordance with the Indonesian National Qualification Framework/Kerangka Kualifikasi Nasional Indonesia (KKNI), are at level 5, which requires the following abilities: 1). Able to complete extensive work, choose the appropriate method from a variety of options that have been or have not been standardized by analyzing data, and able to show performance with measurable quality and quantity; 2) Mastering the theoretical concepts of certain areas of knowledge in general, as well as being able to formulate procedural problem solving; 3) Able to manage the working group and prepare a comprehensive written report; 4). Responsible for their own work and can be given responsibility for the achievement of group work $[1,2]$.

Competency exam of third diploma students of sanitation of Politeknik Kesehatan Kemenkes Maluku in 2019, showed that the graduation rate is still below 20\%. In session I in August 2019, out of 97 students, only 4 people graduated, while in session II in October from 41 re-taker participants there were 6 who graduated. The low graduation rate of this competency test is certainly related to the level of skills possessed by graduates [3].

To perform the procedural competence of these students, definitely, standard operational procedures (SOP) are required for each course practice. The use of SOP can be useful as a reference and give direction clearly related to the procedure of implementation of activities [4]. As for assessing whether students have had such procedural competencies, a valid and reliable measuring instrument is required. Measuring instruments or assessment instruments become so important, when we want to know the level of competence of students and whether they are able to absorb all the content that has been taught. Valid and reliable instruments are not only limited to measurement instrument of competence alone and give an impact to 
the results of assessments or measurements carried out, but more than that. A good assessment instrument is even able to help lecturers, instructors and students in the learning process [5].

\section{OBJECTIVES}

This study aims to prepare the critical competency assessment instrument of third diploma students of sanitation program, based on Standard Operational Procedure (SOP) of course practice.

\section{RESEARCH METHOD}

\subsection{Types of Research}

The type of research used in this study is applied research. Where cohort studies conducted on groups of lecturers and instructors of practical courses.

\subsection{Research Object}

The object of the research is all lecturers and instructors who are masters of practical courses in the third diploma sanitation program. In addition, the object in this study is the critical competency assessment instrument.

\subsection{Data Collecting and Processing}

a. Preparation of SOPs for each practical course

b. Preparation of student critical competency assessment instruments for each practical course

c. Evaluation and discussion of SOP and assessment instrument with all lecturers and instructors of practical courses

d. Review and revision of SOP and assessment instrument

e. Expert Review

f. Evaluation and improvement as a follow-up to the development of SOP and assessment instruments

g. Data processing is done either manually or by using a computer

\section{A. Data Analysis}

The data collected in this study were qualitatively analyzed. Student practice assessment instruments are reviewed by lecturers and instructors who master practical courses using review instruments adapted from learning object review instrument /LORI [6]. In addition, this assessment instrument is also reviewed by experts in the field of education of health workers, especially third diploma of sanitation.

\subsection{Data Presentation}

The processed data is presented both tabularly and textually

\section{RESULTS}

This research resulted in the establishment of Standard Operational Procedure (SOP), Work Instruction, as well as The Format of Student Practice Assessment which is prepared based on the SOP /Work Instruction (SOP-Based Assessments). The resulting documents are for 10 (ten) practical courses with a total of 88 (eighty-eight) practical activities, conducted by students of both level I and level II. The assessment format in addition to being reviewed by a health education expert (especially Third Diploma of Sanitation), is also reviewed by all lecturers-instructors who master practical courses in Third Diploma of Sanitation Study Program of Politeknik Kesehatan Kemenkes Maluku. For review by lecturers-instructors of courses using the instrument Learning Object Review Instrument / LORI [6], the assessment scale used is 1 (low) to 5 (high).

\section{DISCUSSION}

The results of a review by 16 (sixteen) lecturers and instructors using the Learning Object Review Instrument/LORI [6], showed that: 10 people $(62.50 \%)$ rated 4 (four) for accurate assessment of students' practical ability, 10 people $(62.50 \%)$ rated 5 (five) for SPECIFIC and DETAILED in measuring student practice ability, 9 people $(56.25 \%)$ provide a score of 4 (four) for the consistency of the instrument in measuring the ability of students in a varied context, 8 people (50\%) provide a score of 4 (four) for the ability of instruments in describing student learning achievements in general, 8 people $(50 \%)$ provide a score of 4 (four) for the ability of instruments in providing feedback on student learning outcomes in general, 9 people $(56.25 \%)$ rated 4 (four) for instrument ability in motivating and attracting students' learning interest, and 11 people $(68.75 \%)$ provide a value of 5 (five) for clarity and ease in understanding the use of instruments, as well as 8 people $(50 \%)$ provide a value of 5 (five) for aspects of conformity of the assessment format with standard operational procedures (SOP) practices. Broadly speaking, lecturers and instructors respond positively to this practice assessment instrument that is being developed. An assessment instrument should not only be able to measure the results and achievements of students alone, but it would be better if the instrument is able to help catch the process of achieving student 
learning objectives, as well as to motivate students to learn comprehensively and deeply (deep learning)[7,8,9,10]. Students who are at the level of third diploma, as stated in the Indonesian National Qualification Framework/Kerangka Kualifikasi Nasional Indonesia (KKNI), should become health professionals who must be able to carry out health care practices procedurally. Therefore, these procedural skills should be one of the focuses in learning, both during the learning process, and at the time of assessment of learning outcomes.

\section{CONCLUSION}

Currently, health college graduates generally faced the challenge of being able to pass the Health Workers Competency Test/ Uji Kompetensi Tenaga Kesehatan (UKOM-Nakes), including graduates of Diploma III Sanitation. Competency examination becomes a milestone statement whether or not a health worker is competent in carrying out health care practices. In accordance with the level of competency of learning diploma education program contained in the Framework of the Indonesian National Curriculum/Kerangka Kualifikasi Nasional Indonesia (KKNI), a health practitioners must be able to carry out health service procedurally. Assessment instruments produced through this research, later can be used to measure and assess the level of knowledge, understanding, and critical skills, and also able to support the process of knowledge formation, understanding, and skills of students. Based on the review of lecturers and instructors, it can be concluded that this SOP-Based Assessment instrument is appropriate and can be applied to students of third diploma of sanitation.

\section{REFERENCES}

1. Kementerian Kesehatan Republik Indonesia (2007). Keputusan Menteri Kesehatan Nomor: 373/MENKES/SK/III/2007 tentang Standar Profesi Sanitarian.

2. Peraturan Menteri Pendidikan Nasional No. 20 Tahun 2007 Standar Penilaian Pendidikan.

3. Dent, JA \& Harden, RM. (2009). A Practical Guide for Medical Teachers. Third Edition. Elsevier Churchill Livingstone

4. Fatimah, Endah Nur dkk. (2015). Strategi Pintar Menyusun SOP (Standard Operating Procedure). Pustaka Baru Press. Yogyakarta

5. Basuki, I \& Hariyanto. (2015). Asesmen Pembelajaran. Bandung: PT. Remaja Rosdakarya Offset
6. Nesbit John, Belfer, Karen, Leacock, Tracey. 2009 Learning Object Review Instrument (LORI): User Manual

7. Brown, G. \& Atkins, M. (1988) Effective Teaching in Higher Education. London: Methuen

8. Rolfe, I. \& McPherson, J. (1995) Formative assessment : how am I doing? Lancet, 345, 837839

9. Cox, Ken. 1993. Planning Bedside teaching. The Medical Journal of Australia. Vol 158571 - 572

10. Doshi, Monica; Brown, Nick. (2005). Whys and hows of patient-based teaching. Advances in Psychiatric Treatment, vol. 11, 223-231. UK 